\title{
Los factores de competitividad en las pequeñas y medianas empresas y la Responsabilidad Social Empresaria
}

Factors of competitiveness within small and medium enterprises and Corporate Social Responsibility

\author{
Juan Pablo del Barco \\ Facultad Ciencias Económicas, \\ Universidad Nacional del Litoral, \\ Argentina. \\ E-mail: juanpablodelbarco@hotmail.com
}

\section{Resumen}

El debate vinculado a la actuación de la Responsabilidad Social Empresaria (RSE) se está difundiendo en manera siempre mayor y se está buscando en muchos casos pasar de una visión moral y ética de la cuestión a una más estratégica y organizada. Es para destacar que todavía muchas empresas aplican prácticas de RSE en forma estática, desconectada y fragmentada respecto a los objetivos del negocio.

La investigación se centraliza en las PyMEs, considerando que la realidad y características de estas empresas son diversas a la de las grandes empresas.

El trabajo comienza con un análisis de las contribuciones de la doctrina nacional e internacional, terminando con una investigación empírica desarrollada sobre una muestra de empresas de mediana dimensión de dos regiones, la región delle Marche en Italia, y la provincia de Santa Fe en Argentina.

El objetivo principal de la presente investigación es el de comprender cómo y en qué modalidad se puede integrar la RSE en la estrategia empresaria de las PyMEs. Considerando a la RSE como un factor que aporta beneficios a la sociedad y mejora la capacidad competitiva.

Con los resultados se ha demostrado que las PyMEs de ambas regiones desarrollan acciones 0 prácticas de RSE. Sin embargo, estas prácticas frecuentemente son realizadas en forma aisladas, sin una estrategia 


\section{Palabras clave \\ - Responsabilidad Social Empresaria \\ - PyMEs \\ - competitividad \\ - sostenibilidad \\ - gestión sustentable empresarial}

0 gestión integral de RSE. Las diversas acciones que realizan estas empresas pueden ser reagrupadas principalmente en cuatro áreas bien diferenciadas, en las cuales está demostrado su enfoque a la responsabilidad social, en la mayor parte de los casos, sin que estas empresas sean conscientes (es decir, realizando una RSE implícita, informal y silenciosa); las mismas son: los empleados, producto/calidad, el medioambiente y la cadena de valor (proveedores y clientes).
- Corporate Social Responsibility

- SME

- competitive

- sustainability

- sustainable business management

\begin{abstract}
Discussions related to the role CRS plays are spreading out every time in a major way and it is being attempted in many cases to move from a moral and ethical vision of the subject to a more strategical and organizational one. However, it should be pointed out that many companies still apply CRS techniques in a static, disconnected and fragmented way in respect of their business objectives.

The study is circumscribed to SME, considering that the reality and characteristics of these companies are different from those of large enterprises.

This study begins with an analysis of the contributions made by national and international doctrine, finishing with an empirical research conducted on a sample of medium sized companies from two regions, the Marche region in Italy, and the province of Santa Fe in Argentina.

The main purpose of this research is to understand how and in what ways CSR can be integrated into SME's business strategy. Considering CSR as a factor that is beneficial to society and that improves the competitive ability.

With the investigation 's results it has been shown that SME from both regions perform actions or practices of CSR. However, these practices are usually performed isolatedly, without a strategy or integral management of CSR. The different actions these companies implement can be mainly grouped into four areas well differentiated, in which are demonstrated their approach to social responsibility, in most cases, without these companies being aware (i.e. carrying out an implicit, informal and silent CSR); these areas are: employees, product / quality, environment and the supply chain (suppliers and customers).
\end{abstract}

